\title{
Moths provide a model
}

\section{London}

THE UK Department of the Environment (DoE) is to fund a three-year $£ 390,000$ project to monitor the spread of a small Mediterranean moth now invading southern England, in the hope that the data will help to predict what would happen if genetically engineered insects were to be released in the future.

The firethorn leaf-miner moth Phyllonorycter leucographella was first noticed in Essex last year, and is still restricted to that county. Its caterpillars feed exclusively on firethorn Pyracantha spp., a common garden shrub. Professor John Lawton, from Imperial College's population biology centre in Ascot, who is leading the research, says that the moth may have been present in the United Kingdom for only two or three years, and may have been introduced with imported firethorn plants.

The invasion provides an ideal opportunity to study the spread of an insect population, according to Lawton, and will provide information that may influence DoE policy on the monitoring of releases of genetically engineered insects. The DoE believes that adequate monitoring of the release of genetically engin-

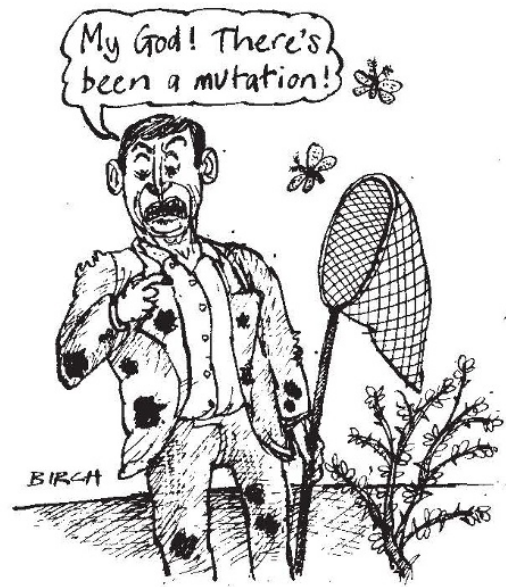

eered insects will be possible, but Lawton suspects that the manpower required may be more than DoE can afford.

In order to see what level of monitoring is needed, Lawton will compare surveys conducted by his own small research team with records from "an army of volunteers", recruited by means of leaflets aimed at local natural history societies, conservation groups and sixth-form biology students. "We may get a nasty shock", he says, as monitoring by a small group of scientists may give a badly distorted picture.

The data collected may also allow biologists to develop better models of population growth. Most existing models examine a population spreading through a homogeneous environment, but the DoE needs models that can predict the spread of released insects in a real "grainy" environment, Lawton says. As yet, there is no detailed information on the spread of any insect in the United Kingdom from which to develop these models. Lawton concedes that the firethorn leaf-miner's population biology may not be a typical example, but he points out that its association with a particular species of plant is useful. Genetically engineered insects may, in future, be used as biological control agents, attacking specific plant or animal pest species.

Commercial releases of genetically engineered insects for biological pest control are several years away, but small experimental releases to address purely academic questions may be a more immediate prospect. One application to release has already been submitted, but was withdrawn before a decision was made, after the UK research councils and British Petroleum declined to fund it.

Lawton is concerned about the prospect of future commercial releases of genetically engineered insects. Possible biological control applications include the production of engineered ladybirds with increased voracity for their insect prey. These genes could enter the wild population, Lawton says, "with quite unforeseen consequences".

Professor David Bishop, from the Institute of Virology in Oxford, a pioneer in the development of genetically engineered virus insecticides, says that more ground work is needed to assess the environmental impact of commercial insect releases. But he is concerned that commercial companies may not wait for these data before applying for permission to release.

Peter Aldhous

\section{Green science thinks bigger}

\section{Washington}

ECologists may not spend much time pacing the halls of Congress, but they seem to recognize a political opportunity when they see one. Faced with unprecedented interest in environmental research and congressional fondness for targeted science programmes, US ecologists are preparing their first shot at the big bucks. Early next year the Ecological Society of America (ESA) will release a broad research strategy for the 1990 s and will also seek several millions of new dollars to finance it.

"For our society this is a landmark document - and a very risky one", says ESA president-elect $\mathbf{H}$. Ronald Pulliam. Known as the "Sustainable Biosphere Initiative", the draft plan embraces much present ecology research, which will be repackaged to highlight its application to global environment issues.

But planners concede that they may risk angering some ecologists by their intention to assign priorities to their goals. Congress and the federal funding agencies are not stupid, they argue, and too broad an initiative dressing all continuing research in a fashionable green would fool nobody. Some current research must of necessity be left by the wayside.

So far, the gamble seems to have paid off. At a meeting of the Ecological Society of America in July, the proposal won solid endorsement. First responses to a 50-page draft sent to 500 scientists for comment suggest that "we're on the right track", according to Jane Lubchenco, the Oregon State University zoologist heading the drafting committee. The committee plans to have the document ready for a congressional briefing early next year, with final publication in April.

The initiative is aimed at two environmental issues that need no selling - global change and biodiversity - and a third, called "sustainable systems", that may. Low-input agriculture is the common example of a sustainable system: with careful intermingling of complementary species, farm land can be made productive with minimal use of pesticides, fertilizers and chemicals. Ecologists may see the point, but can farmers be convinced to lend their substantial weight to this part of the initiative? Experience in agricultural biotechnology suggests that that will not be easy.

The initiative goes beyond research to emphasize public education and the application of ecology to public policy, which will entail convincing legislators and the public that ecology offers a cheap and intelligent way to solve environmental problems. ESA will then seek federal endorsement of the initiative, either by the Congress or the White House.

New money is, of course, likely to be a stumbling block, but ESA planners hope their document will extract funds from half a dozen federal agencies that already support environmental work.

There are some encouraging signs. A recent National Science Board report recommended $\$ 20-\$ 50$ million in new support for biodiversity research. Large ecological projects costing as much as $\$ 200$ million have been advocated as part of the study of climate change. And earlier this year, the National Academy of Sciences recommended another $\$ 270$ million over ten years for more forestry research, motivated partly by global warming concerns.

Christopher Anderson 